\title{
Formulation of gastroresistant tablets containing sodium alendronate-loaded blend microparticles
}

\author{
Luana Mota Ferreira, Aline de Arce Velasquez, Scheila Rezende Schaffazick, Letícia Cruz*
}

\author{
Department of Industrial Pharmacy, Federal University of Santa Maria, Santa Maria, RS, Brazil
}

\begin{abstract}
Sodium alendronate is an antiresorptive drug used for the treatment of postmenopausal osteoporosis. However, its oral administration is associated with low bioavailability and gastroesophageal irritation. This work aimed at developing tablets containing sodium alendronate-loaded microparticles by direct compression to achieve a safe and effective form. The parameters evaluated were average weight, hardness, thickness and drug content. In vitro release tests were carried out using simulated gastric and intestinal fluids, and the profiles were analyzed through the Korsmeyer-Peppas mono- or biexponential dependent approaches. Tablets presented adequate average weight, thickness, good mechanical properties and drug content close to $100 \%$. Moreover, the formulation released less than $11 \%$ of sodium alendronate in gastric fluid, exhibiting a good gastroresistance. At $\mathrm{pH} 6.8$, almost $100 \%$ of the drug was released in $12 \mathrm{~h}$, showing a prolonged profile. The mathematical modeling indicated that the experimental data was better fitted to the biexponential equation. Furthermore, a good correlation coefficient was obtained for the Korsmeyer-Peppas model and the release exponent suggested that the drug dissolution was driven by anomalous transport. In conclusion, the microparticulated tablets can be considered a promising alternative for oral delivery of sodium alendronate.
\end{abstract}

Uniterms: Microparticulated tablets/release profile. Sodium alendronate/oral administration. Sodium alendronate/controlled release/in vitro study.

O alendronato de sódio é um fármaco da classe dos bisfosfonatos, comumente utilizado no tratamento da osteoporose pós-menopausa. Entretanto, sua administração oral está associada à baixa biodisponibilidade e irritação gastroesofágica. Este trabalho objetivou o desenvolvimento de comprimidos contendo micropartículas de alendronato de sódio por compressão direta, a fim de obter uma forma segura e eficaz. Os parâmetros avaliados foram peso médio, dureza, espessura e teor de fármaco. Estudos de liberação in vitro foram realizados utilizando fluído gástrico e intestinal simulado e o perfil de liberação foi analisado pelos modelos matemáticos de Korsmeyer-Peppas, mono- e biexponencial. Os comprimidos apresentaram peso médio adequado, espessura, dureza e teor próximo a 100\%. Além disso, a formulação liberou menos de $11 \%$ do fármaco em fluído gástrico, mostrando uma boa gastrorresistência. Em pH 6,8, em torno de $100 \%$ do fármaco foram liberados em $12 \mathrm{~h}$, apresentando liberação prolongada. A modelagem matemática indica que os resultados seguem a equação biexponencial. Pela análise do expoente de liberação obtido no modelo de Korsmeyer-Peppas sugere-se que a dissolução do fármaco ocorre por transporte anômalo. Concluindo, a preparação dos comprimidos microparticulados pode ser considerada uma alternativa promissora para a liberação oral do alendronato de sódio.

Unitermos: Comprimidos microparticulados/perfil de liberação. Alendronato de sódio/administração oral. Alendronato de sódio/liberação controlada/estudos in vitro.

*Corresponding: L. Cruz. Departamento de Farmácia Industrial. Universidade Federal de Santa Maria - 97105-900 - Santa Maria - RS, Brasil. E-mail: leticiacruz@smail.ufsm.br 


\section{INTRODUCTION}

Sodium alendronate is an antiresorptive drug belonging to the class of bisphosphonates used to prevent and treat postmenopausal osteoporosis (Perez-Lopez, 2004). Sodium alendronate is marketed as tablet. However, it presents poor oral absorption and upper gastrointestinal adverse events, such as esophageal and gastric irritation, the major reasons for the discontinuation of the therapy (Li, Kendler, 2004).

To prevent the side effects and to maximize its absorption, sodium alendronate tablets should be taken with a full glass of water, and patients should not lie down for at least 30 min after ingestion. Moreover, no food should be eaten immediately after the ingestion of this medicine (Li, Kendler, 2004). These dosing recommendations are associated with poor therapeutic adherence (Reginster, Rabenda, Neuprez, 2006). In this context, the design of a drug carrier with suitable properties could be a promising alternative for the oral delivery of bisphosphonates.

In a previous work (Cruz et al., 2010), we reported the preparation of sodium alendronate-loaded microparticles by spray-drying. The formulation was composed of a blend of Eudragit $\mathrm{S} 100^{\circledR}$, an enterosoluble polymer, and Methocel K15M ${ }^{\circledR}$, a controlled release cellulose derivative. In vitro release experiments showed that the microparticles presented an adequate gastroresistance combined with a prolonged drug release for $12 \mathrm{~h}$. After oral administration to rats, drug-loaded microparticles were able to prevent the bone loss in ovariectomized animals. Moreover, rats that received sodium alendronate-loaded microparticles exhibited an ulcerative lesion index significantly lower compared to the group treated with the drug solution. Therefore, these microparticles were considered promising carriers for the oral delivery of sodium alendronate.

Despite the great potential presented by the microparticles, this type of drug delivery system is rarely used directly in its powdered form. For this reason, the goal of the present study was the preparation and characterization of tablets containing sodium alendronateloaded blend microparticles. The development of this type of formulation is considered a difficult task, due to the fact that the particle must withstand the compression force in order to avoid its rupture or deformation with consequent loss of gastroresistance and increased dissolution rates. The deformation or rupturing of microparticles after compression is the reason why only a few microparticulate formulations are commercially available. In addition, tablets were chosen as the final dosage form due to their popularity, convenience of dosing, ease of manufacture, stability and release mechanism (Jivraj, Martini, Thomson, 2000).

\section{MATERIAL AND METHODS}

\section{Material}

Monosodium alendronate trihydrate was purchased from Pharma Nostra (São Paulo, Brazil). Methocel ${ }^{\circledR}$ K15M (hydroxypropyl methylcellulose) was kindly donated by Colorcon (Cotia, Brazil), and Eudragit ${ }^{\circledR}$ S100 (Poly(methacylic acid-co-methyl methacrylate) 1:2 ) was obtained from Degussa (São Paulo, Brazil). $o$-Phtalaldehyde (OPA) was purchased from SigmaAldrich (São Paulo, Brazil), and 2-mercaptoethanol was acquired from Acros Organics (Geel, Belgium). Microcrystalline cellulose (Avice ${ }^{\circledR}$ PH101) was purchased from FMC corporation (Philadelphia USA), poly(vinyl pyrrolidone) (PVP - Kollidon ${ }^{\circledR} 30$ ) from Delaware (Porto Alegre - Brazil), and stearate magnesium was obtained from Henrifarma (São Paulo Brazil). All other solvents and reagents were of analytical grade and used as received.

\section{Preparation and characterization of microparticles}

Sodium alendronate-loaded microparticles $(n=3)$ were prepared by spray-drying, as previously described (Cruz et al., 2010). Briefly, Eudragit ${ }^{\circledR} \mathrm{S} 100(5.0 \mathrm{~g})$ was dissolved in $0.05 \mathrm{~mol} / \mathrm{L} \mathrm{NaOH}(500 \mathrm{~mL})$ under magnetic stirring at $50^{\circ} \mathrm{C}$. Then, Methocel ${ }^{\mathbb{R}} \mathrm{K} 15 \mathrm{M}(2.5 \mathrm{~g})$ was added, and the mixture remained under mechanical stirring for $15 \mathrm{~min}$. The formed gel was kept at $4{ }^{\circ} \mathrm{C}$ for $24 \mathrm{~h}$. Sodium alendronate $(2.0 \mathrm{~g})$ was added in the gel before spraydrying. Operational conditions were the following: feed rate of $0.33 \mathrm{~L} / \mathrm{h}$, air flow rate of $70 \mathrm{~nL} / \mathrm{h}$, atomizing air pressure of $3.0 \mathrm{kgf} / \mathrm{cm}$, inlet temperature of $150{ }^{\circ} \mathrm{C}$ and nozzle diameter of $1.2 \mathrm{~mm}$. The resultant powders were stored in a desiccator. The yield was calculated by the ratio of the experimental weight and the sum of the weights of all components, disregarding the water content. Encapsulation efficiency was determined spectrophotometrically at $333 \mathrm{~nm}$ using OPA as derivatizing agent (Cruz et al., 2009). Size and size distributions of microparticles were analyzed by laser diffractometry (Malvern Mastersizer, 2000 Inserir referência na parte reference, Malvern Instruments, UK). Moisture content was assayed using an infrared drying equipment (Gehaka IV 2500) kept at $115^{\circ} \mathrm{C}$ until constant weight. Bulk density $\left(\rho_{\mathrm{b}}\right)$ was determined by transferring $2.0 \mathrm{~g}$ of microparticles to $25 \mathrm{~mL}$ graduated cylinder. The 
powder volume was determined and then the bulk density was calculated. The sample contained in the measuring cylinder was tapped 1250 times using a Pharmatest PT-TD to obtain the tapped density $\left(\rho_{t}\right)$. Carr index and Hausner ratio were determined from the values of the bulk and tapped densities results.

\section{Preparation and characterization of tablets containing microparticles}

Tablets with theoretical weight of $750 \mathrm{mg}$ were prepared by the direct compression of powders. Previously, an amount of microparticle corresponding to $70 \mathrm{mg}$ of sodium alendronate was mixed with microcrystalline cellulose $(12 \%)$ as diluent, PVP $(15 \%)$ as dry binder, and magnesium stearate $(0.75 \%)$ as lubricant in a glass mortar. A single punch machine (Neuberger) was used for powder compression. An exact amount of the powder mixture was filled in a die using a little pressure and then, hydraulic pressure $\left(400 \mathrm{kgf} / \mathrm{cm}^{2}\right)$ was employed to form the tablets. After the preparation, tablets were characterized according to average weight (analytical balance - Shimadzu AY220), thickness (manual caliper), hardness (portable hardness tester Off Tec Galileo) and drug content using the same method mentioned for the microparticles. In vitro release tests were carried out using USP Apparatus 1: basket, $100 \mathrm{rpm}$ at $37^{\circ} \mathrm{C}$ (USP, 2008). The gastroresistance of the tablets was evaluated in $900 \mathrm{~mL}$ of simulated gastric fluid, compound $0.1 \mathrm{~mol} / \mathrm{L} \mathrm{HCl}(\mathrm{pH} 1.2)$, until $2 \mathrm{~h}$ of experiment, while dissolution profile was studied in $900 \mathrm{~mL}$ of simulated intestinal fluid, containing phosphate buffer $\mathrm{pH}$ 6.8, during $12 \mathrm{~h}$. The drug dissolved at specified periods was plotted as percent release versus time curve. Sodium alendronate release was analyzed by modeldependent approaches: monoexponential (Equation 1) and biexponential (Equation 2).

$$
\begin{gathered}
\frac{M_{t}}{M_{\infty}}=1-\left[e^{-k t}\right] \\
\frac{M_{t}}{M_{\infty}}=1-\left[A \cdot e^{-\alpha . t}+B \cdot e^{-\beta . t}\right]
\end{gathered}
$$

where $M_{t}$ is the amount of the drug released at time $t, M_{\infty}$ is the initial concentration of the drug, $k, \alpha$ and $\beta$ are the apparent release kinetic rate constants, $A$ and $B$ are the fractions of the drug that contributed to the burst and sustained phases, respectively.

The release mechanism of sodium alendronate from tablets was analyzed by fitting experimental data to Korsmeyer-Peppas model (Equation 3).

$$
f t=\frac{M_{t}}{M_{\infty}}=k \cdot t^{n}
$$

where $f t$ is the ratio of the absolute cumulative amount of drug released at time $t$ and at infinite time, $k$ is a constant incorporating structural and geometric characteristic of the carrier, and $n$ is the release exponent, indicative of the drug release mechanism.

In all cases, the fit was performed using the Scientist 2.0 software (Micromath, USA). The selection of the model was based on the best correlation coefficient and the best model selection criteria (MSC), both provided by the software, and the best graphic adjustment.

\section{Statistical analysis}

The data were analyzed by Student's t-test, oneway and two-way ANOVA. Significance level was set at $\mathrm{p}<0.05$.

\section{RESULTS AND DISCUSSION}

Following preparation, microparticles were presented as finely divided white powder. Regardless of the presence of the drug, the formulations were obtained with a yield of about $40 \%$. Powder loss may be due to the adhesion of sprayed droplets to the internal walls of the equipment and the poor efficiency of cyclone in collecting fine particles. Sodium alendronate-loaded microparticles had encapsulation efficiency of $85.7 \pm 0.9 \%$, which corresponds to a drug loading of $155.7 \pm 1.7 \mathrm{mg} / \mathrm{g}$. In our previous work (Cruz et al., 2010), we reported a lower encapsulation efficiency of $79.7 \pm 0.9 \%$, despite the same operational conditions. Regarding particle size, the mean diameter $\left(d_{4,3}=5.8 \mu \mathrm{m}\right)$ and span (1.5) found in this work were lower than the values previously reported (Cruz et al., 2010). These differences found for encapsulation efficiency and particle diameters are associated with the fact that the spray-dryer used here is not the same equipment employed for the preparation of microparticles in our previous work. Concerning moisture content, this parameter was evaluated for the first time for sodium alendronate-loaded blended microparticles and showed water content of $6.35 \pm 0.1 \%$. As for powder densities, the microparticles showed $0.12 \pm 0.01 \mathrm{~g} / \mathrm{cm}^{3}$ and $0.19 \pm 0.03 \mathrm{~g} / \mathrm{cm}^{3}$ for bulk and tapped density, respectively. The flow properties are expressed in terms of Carr index and Hausner ratio. Sodium alendronate-loaded microparticles presented Carr index of $36.8 \pm 0.04 \%$ and Hausner ratio of $1.57 \pm 0.10$. Both values indicate poor 
flow properties. However, the addition of excipients can improve powder flowability.

In order to prepare tablets containing sodium alendronate-loaded microparticles, previous trials were performed to select the best diluent (starch, lactose and microcrystalline cellulose) and the optimal PVP concentration $(2.5,5.0,10.0$ and $15.0 \%)$. Results showed a great variation in tablet weight using lactose or starch (data not shown). Moreover, PVP concentrations below $15.0 \%$ resulted in tablets with low hardness (less than $3.0 \mathrm{kgf}$ ). On the other hand, tablets presenting good mechanical properties and low weight variation were obtained using microcrystalline cellulose as diluent and $15.0 \%$ of PVP as dry binder. After preparation, the tablets containing microparticles presented an average weight of $748 \pm 19 \mathrm{mg}$, thickness of $0.4 \pm 0.0 \mathrm{~cm}$, adequate hardness of $9.2 \pm 0.3 \mathrm{kgf}$, and sodium alendronate content of $99 \pm 10 \%$. As previously reported, the increase in the PVP concentration resulted in improved tablet hardness (Patel, Amin, 2011). In addition, cellulose can significantly improve tablet hardness, due to its plastic properties (Zhang, Law, Chakrabarti, 2003).

For gastroresistance check, tablets containing microparticles were evaluated in simulated gastric fluid. Within $120 \mathrm{~min}, 10.9 \%$ of sodium alendronate was released from tablets (Figure 1). Although a little portion of drug was released, this result is in accordance with the United States Pharmacopoeia specifications. On the other hand, dissolution profiles at $\mathrm{pH} 6.8$ showed that the totality of the drug was released in $720 \mathrm{~min}$ (Figure 1). The in vitro releases of sodium alendronate showed here are very similar to those reported for untableted microparticles (Cruz et al., 2010). The similarity of results obtained for

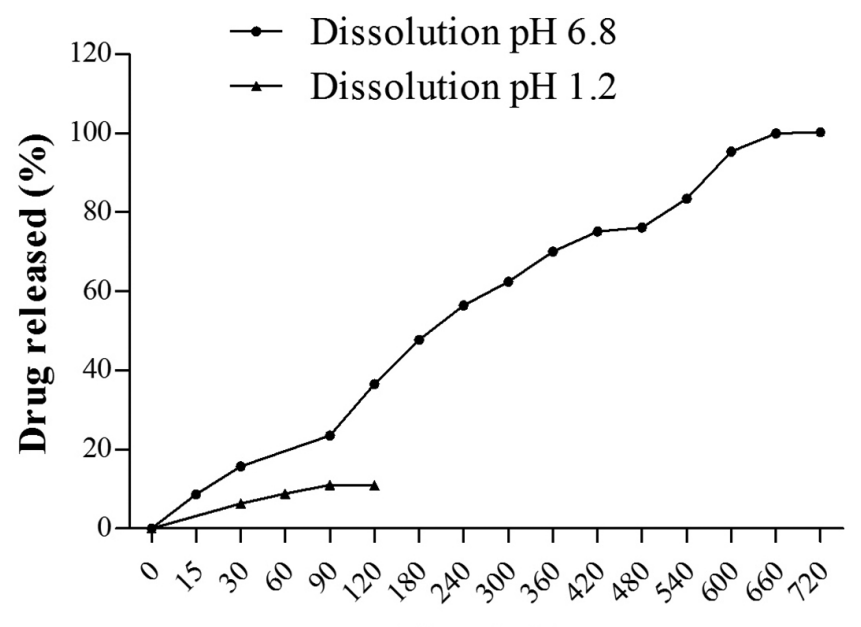

Time (min)

FIGURE 1 - Dissolution profiles of sodium alendronate from tablets containing microparticles at $\mathrm{pH} 1.2$ and $\mathrm{pH} 6.8$. microparticles before and after compression suggests that when microparticles were tableted, the particles remained intact within the tablet without undergoing major deformation and hence, drug release took place from the individual microparticles.

In order to understand the dissolution profile, data were fitted to mono- and biexponential equations. By comparing the values of correlation coefficient and MSC (Table I), the release of sodium alendronate was better described by the biexponential equation. In this case, the release profile presents two phases, the first step, related to the burst effect (apparent rate constant $\alpha$ ), and the other one corresponding to the slow phase (apparent rate constant $\beta$ ). Results showed that about $10 \%$ of the drug is responsible for the burst effect with a kinetic constant $\alpha$ of $0.4122 \pm 0.0009 \mathrm{~min}^{-1}$, while the major part of sodium alendronate $(90 \%)$ was released in the slow phase with a kinetic constant $\beta$ of $0.0028 \pm 0.0011 \mathrm{~min}^{-1}$. It is important to mention that untableted microparticles also followed biexponential behavior. However, $15 \%$ of the drug was associated with the burst effect, while approximately $85 \%$ of sodium alendronate was released in the slow phase.

TABLE I - Parameters of mathematical modeling

\begin{tabular}{lc}
\hline Models/Parameters & \\
\hline Monoexponential & \\
$\quad k\left(\mathrm{~min}^{-1}\right)$ & $0.0033 \pm 0.0004$ \\
$r$ & 0.9805 \\
$\quad$ MSC & 2.7401 \\
Biexponential & \\
$\alpha\left(\mathrm{min}^{-1}\right)$ & $0.4122 \pm 0.0009$ \\
$\beta\left(\mathrm{min}^{-1}\right)$ & $0.0028 \pm 0.0011$ \\
$A$ & $0.0998 \pm 0.0015$ \\
$B$ & $0.9004 \pm 0.0010$ \\
$r$ & 0.9901 \\
$\quad$ MSC & 3.5219 \\
Korsmeyer-Peppas & \\
$k$ & $0.047 \pm 0.011$ \\
$n$ & $0.523 \pm 0.017$ \\
$r$ & 0.9937 \\
\hline
\end{tabular}

To understand the drug release mechanism, data were also fitted to the Korsmeyer-Peppas model. Regarding the literature (Peppas, 1985), values of release exponent $n$ ranging from 0.43 to 0.85 indicate anomalous transport. Thus, sodium alendronate release from tablets containing microparticles is driven by polymer relaxation 
and drug diffusion (anomalous behavior), as observed for untableted formulation.

\section{CONCLUSION}

Sodium alendronate-loaded blend microparticles were successfully tableted showing adequate technological properties. Therefore, the gastroresistant tablets can be considered a promising formulation to be used in the oral treatment of osteoporosis. Further preclinical and clinical studies are needed to confirm its therapeutic potential.

\section{ACKNOWLEDGEMENTS}

The authors thank CNPq/Brazil and FIPE/UFSM/ Brazil Program for the financial support. They also thank C.B. da Silva for providing access to spray drying and A. R. Pohlmann and S.S. Guterres for the laser diffraction analyses.

\section{REFERENCES}

CRUZ, L.; ASSUMPÇÃO, E.; GUTERRES, S.S.; POHLMANN, A.R. High encapsulation efficiency of sodium alendronate in eudragit s100/hpmc blend microparticles. Quím. Nova, v.32, n.5, p.1170-1174, 2009.

CRUZ, L.; ASSUMPÇÃO, E.; ANDRADE, S.F.; CONRADO, D.J.; KULKAMP, I.C.; GUTERRES, S.S.; POHLMANN, A.R. Gastroresistant microparticles containing sodium alendronate prevent the bone loss in ovariectomized rats. Eur. J. Pharm. Sci., v.40, n.5, p.441-447, 2010.

JIVRAJ, M.; MARTINI, L.G.; THOMSON, C.M. An overview of the different excipients useful for the direct compression of tablets. Res. Focus, v.3, p.58-63, 2000.
LI, W.W.; KENDLER, D.L. Pharmaceutical care and community pharmacists' understanding of bisphosphonate dosing information. J. Clin. Pharm. Ther., v.29, n.6, p.531-536, 2004.

PATEL, M.M.; AMIN, A.F. Process, optimization and characterization of mebeverine hydrochloride loaded guar gum microspheres for irritable bowel syndrome. Carbohyd. Polym., v.86, n.2, p.536-545, 2011.

PEPPAS, N.A. Analysis of fickian and non-fickian drug release from polymers. Pharm. Acta Helv., v.60, n.4, p.110-111, 1985.

PEREZ-LOPEZ, F.R. Postmenopausal osteoporosis and alendronate. Maturitas, v.48, n.3, p.179-192, 2004.

REGINSTER, J.Y.; RABENDA, V.; NEUPREZ, A. Adherence, patient preference and dosing frequency: Understanding the relationship. Bone, v.38, n.4, p.S2-S6, 2006.

USP-United States Pharmacopoeia. US Pharmacopeial Convention. 31 th ed. Rockville: The United State Convention, 2008.

ZHANG, Y.; LAW, Y.; CHAKRABARTI, S. Physical properties and compact analysis of commonly used direct compression binders. AASP PharmaSciTech, v.4, article 62, 2003.

Received for publication on $10^{\text {th }}$ February 2014 Accepted for publication on $02^{\text {nd }}$ November 2014 
